IZA DP No. 9197

Family Shocks and Academic Achievement

Marie Hull

July 2015 


\title{
Family Shocks and Academic Achievement
}

\author{
Marie Hull \\ University of North Carolina at Greensboro \\ and IZA
}

Discussion Paper No. 9197

July 2015

IZA

P.O. Box 7240

53072 Bonn

Germany

Phone: +49-228-3894-0

Fax: +49-228-3894-180

E-mail: iza@iza.org

\begin{abstract}
Any opinions expressed here are those of the author(s) and not those of IZA. Research published in this series may include views on policy, but the institute itself takes no institutional policy positions. The IZA research network is committed to the IZA Guiding Principles of Research Integrity.

The Institute for the Study of Labor (IZA) in Bonn is a local and virtual international research center and a place of communication between science, politics and business. IZA is an independent nonprofit organization supported by Deutsche Post Foundation. The center is associated with the University of Bonn and offers a stimulating research environment through its international network, workshops and conferences, data service, project support, research visits and doctoral program. IZA engages in (i) original and internationally competitive research in all fields of labor economics, (ii) development of policy concepts, and (iii) dissemination of research results and concepts to the interested public.
\end{abstract}

IZA Discussion Papers often represent preliminary work and are circulated to encourage discussion. Citation of such a paper should account for its provisional character. A revised version may be available directly from the author. 


\section{ABSTRACT}

\section{Family Shocks and Academic Achievement ${ }^{*}$}

Disruptions in family life can take many forms, but all have the potential to impact student learning. With school administrative data matched to birth records, I estimate the effect of unexpected changes in the home environment, or family shocks, on achievement. Identification comes from siblings observed in the same year. I find that family shocks are at least as important as teacher assignment for student learning. Furthermore, they have a relatively larger impact on students from affluent families; time use evidence indicates that this is likely because affluent parents are more involved in their children's learning.

JEL Classification: J24, I21, I24

Keywords: education, human capital, family dynamics, educational inequality, time inputs

Corresponding author:

Marie Hull

Department of Economics

University of North Carolina at Greensboro

PO Box 26170

Greensboro, NC 27402-6170

USA

E-mail: mchull2@uncg.edu

\footnotetext{
* I would like to thank my advisor, Peter Arcidiacono, and the members of my dissertation committee, Hugh Macartney, Arnaud Maurel, and Seth Sanders, for advice and encouragement. I would also like to thank Jared Ashworth, Esteban Aucejo, Brian Clark, Tyler Ransom, Jesse Rothstein, and seminar participants at Duke University, UC Berkeley, Utah State, SUNY Buffalo, and UNC Greensboro for helpful discussions and comments on earlier drafts. I am grateful to the North Carolina Education Research Data Center and the North Carolina State Center for Health Statistics for access to the data.
} 
Disruptions in family life can take many forms: parental job loss, divorce, illness or death in the family. Not all changes are negative. Parents may alter their work schedules to accommodate their children, or family income may unexpectedly increase through a bequest. Each of these changes qualifies as a shock to the family environment that may impact student learning. However, the causal effects that these family shocks have on educational outcomes have proven difficult to establish ${ }_{1}^{1}$ Furthermore, after a shock takes place, it is unclear which mechanisms are behind any change in outcomes. Depending on how shocks translate into student outcomes, we might expect students from some families to suffer more than others after experiencing the same size shock to their home environment. Recent debates in the economics of education have focused on what school inputs and interventions are most effective, while changes in family life and their effect on education have received less attention. Understanding how families contribute to academic achievement is important in its own right, but it also deserves attention since families and schools may play complementary roles in student learning.

In this paper, I abstract from specific types of family shocks and study how unexpected changes in the family environment impact student test scores. I estimate a model of test score production that controls for student ability, past inputs, and school quality. Then, I separate the residual into a family-yearspecific component, or family shock, and an error. I identify family shocks from sibling pairs observed in the same year. Rich administrative school data from North Carolina matched to birth records from the state yields a sample of 5 million student-year observations with a family link. Given my formulation, the family shock parameter is best understood as a net family shock, or the total effect of various family shocks. By abstracting from specific shocks, I can speak more generally about how changes at home go on to affect student

\footnotetext{
${ }^{1}$ For the effect of parental job loss on student outcomes, see Kalil and Ziol-Guest (2008) and Stevens and Schaller (2011). For reviews on the effect of divorce, see Amato and Keith (1991) and Amato (2001), and for changing family arrangements, see Tillman (2007). The most convincing evidence on the effect of an income-derived family shock comes from a few studies that use changes in government income transfers (Duncan, Morris and Rodrigues, 2011: Milligan and Stabile, 2011: Dahl and Lochner, 2012). However, these studies by nature focus on low- and middle-income families.
} 
learning and delve into the underlying mechanisms. My framework also lets me analyze why children from some families are more susceptible to shocks than others.

I find that family shocks play an important role in a student's academic achievement. A one standard deviation shock to the family environment leads to a 0.13 standard deviation change in a student's math score and a 0.15 standard deviation change in reading score. These estimates are on par with, if not larger than, recent estimates of teacher value-added from Chetty, Friedman and Rockoff (2014a). They find that a one standard deviation change in teacher quality moves math scores by 0.14 standard deviations and English scores by 0.1 standard deviations..$^{2}$ One can think of both teacher assignment and family shocks as yearlong events in a student's life. In this paper, I show that a one standard deviation change in family inputs is at least as important as a one standard deviation change in teacher quality in terms of its impact on test scores.

The development of the teacher quality literature offers a useful analogy for the methods, interpretation, and importance of the results in this paper. From Hanushek (1971) to Kane, Rockoff and Staiger (2008), studies have found inconsistent evidence that observable teacher characteristics have an impact on student learning. However, with the rise of large, administrative data sets and increased computing power, our understanding of the impact of teacher quality has changed. Studies such as Rockoff (2004) and Rivkin et al. (2005) were among the first to leverage the fact that we observe a teacher teach many students over time in order to estimate the total impact of having an effective teacher ${ }^{3}$ They revealed that observable characteristics only explain a small fraction of the total variation in teacher quality.

Similarly, past studies have primarily found small impacts of observable

${ }^{2}$ These estimates are typical in this literature. Rockoff (2004), Rivkin, Hanushek and Kain (2005), Aaronson, Barrow and Sander (2007), and Kane and Staiger (2008) all put the impact of a one standard deviation better teacher on test scores between 0.08 and 0.15 standard deviations. Rothstein (2014) replicates Chetty et al.'s (2014a) results with the school data used in this paper and reproduces all key results on teacher value-added.

${ }^{3}$ Earlier studies such as Hanushek (1971) and Murnane (1975) employ a similar logic but are limited by data availability. 
family shocks on student outcomes. For example, in their preferred specification, Stevens and Schaller (2011) find that parental job loss increases the probability of grade repetition by 0.008 with a standard error of 0.004 . Furthermore, the causation for some observable family shocks is so difficult to establish that only descriptive studies exist. Take the case of divorce. Amato and Keith (1991) demonstrate a negative association between divorce and a host of cognitive and social outcomes. Within the context of family shocks, major fights or the initial separation may be more disruptive than the finalization of the divorce. However, these potentially more important events are likely unobserved. In this study, I leverage the fact that I observe multiple siblings in a year to infer the total impact of family shocks on test scores. A unique data set from North Carolina that merges school administrative data and birth records makes this study possible ${ }^{4}$ As with teachers, I find that the total variation in family shocks is quite large relative to the impacts of observed family shocks.

After establishing the net impact of a family shock, I explore whether children from some families are more vulnerable to family shocks than others. In other words, does a one standard deviation change in family inputs have a larger impact on some students than others? The way that differences among families might play out is not clear. Consider a negative family shock to student achievement. In disadvantaged families, parents might have limited ability to shield their children from the shock, while affluent parents may be better able to substitute other inputs to offset it. On the other hand, parents from affluent families might be more involved in their children's learning initially, and so their children might suffer more from a change in their time spent together. If the parents are already uninvolved, the child has less to lose when parental resources are stretched thin. Another factor is the type of shock that leads to the change in test scores since some families are more likely to

${ }^{4}$ The only other similarly linked data set comes from Florida. Figlio, Guryan, Karbownik and Roth (2014) uses this data to study the effect of neonatal health on educational outcomes. A handful of recent papers also use the matched North Carolina data, mostly to study the impact of early childhood education on later outcomes, but no other paper to my knowledge uses the mother identifier. 
experience certain shocks than others. Here, I focus on the net impact of a one standard deviation shock.

I take advantage of two features of my data to shed light on the heterogeneity in family shocks and the mechanisms behind them. The first is demographic information in the education and birth data sets that lets me analyze family shocks by family characteristics. The second is time use variables collected at the time of testing: time spent using a computer, free reading, doing homework, and watching television. The free reading and homework variables are particularly informative since educational activities like these are the most productive uses of time for cognitive development (Fiorini and Keane, 2014). Taken together, these variables tell me how family shocks affect students' home activities and how family shocks to time use move with family shocks to achievement.

The evidence supports the hypothesis that shocks to affluent families lead to bigger changes in parental involvement, and therefore, shocks in these families have a bigger impact on the children's achievement. First, I show that family shocks to achievement often have a larger impact on children from families with a higher socioeconomic status (SES). For example, the impact of a one standard deviation family shock on math achievement increases significantly in mother's education, father's education, and income. Second, I show that time spent engaged in educational activities also responds more to family shocks when a student has affluent parents. Last, I demonstrate that family shocks to educational time use are more closely related to family shocks to achievement, as compared with family shocks to other uses of time.

In analyzing the net impact of family shocks, I lose the ability to point to a specific event and say precisely how it affects student achievement. However, a more general treatment helps us see the bigger picture of how disruptions to family life influence a child's learning in school. This work serves as a complement to studies on specific family shocks - it is still important to understand the link between specific changes in the family environment and educational outcomes. But in light of the difficulty in establishing causation, a study of the aggregate impact of shocks has value. It establishes basic relationships 
between changes in the home environment and performance at school, along with some of the intervening mechanisms.

The findings in this paper are connected to several strands of literature in the economics of education. Much work has focused on how permanent family characteristics, like parents' education, contribute to inequality in educational outcomes. ${ }^{5}$ Here, I emphasize that changes in family inputs also play a role in educational outcomes as well educational inequality. Negative family shocks decrease the distance between high-SES and low-SES students while positive shocks increase it. Findings on time-varying inputs are especially policy relevant since there is scope to manipulate parents' current inputs whereas permanent family characteristics are by nature fixed.

Another question of interest for policymakers is what interventions are most successful at reducing outcome gaps between poor and rich students, or minority and white students. There is strong evidence that disadvantaged students respond more to improvements in school inputs than affluent students. ${ }^{6} \mathrm{My}$ results suggest that changes in the test scores of advantaged students more likely come from changes at home. However, the school could still play an important role in mitigating the effect of a negative family shock. For example, school administrators and teachers could communicate information about family changes to their colleagues responsible for other members of the family. By providing extra services for all siblings, negative family shocks may not be so detrimental. Finally, while more involved parents may leave their children more vulnerable to negative shocks, they also may provide an extra boost to their children's learning in the event of a positive family shock. This research suggests that home interventions that help parents guide their children toward educationally enriching activities will produce achievement gains at school.

Finally, this paper is related to research in other disciplines on the impact

\footnotetext{
${ }^{5}$ See Björklund and Salvanes $(2011)$ for a review.

${ }^{6}$ For example, Aaronson et al. (2007) show that black students and students with initially lower achievement benefit more from a higher quality teacher. Krueger (1999) finds that small class sizes have a larger effect on minorities and poor students, and Neal (1997) finds that urban minorities benefit more from attending Catholic school. In recent work, Jackson, Johnson and Persico (2015) show that the positive effects of increases in school funding on adult outcomes are larger for low-income students.
} 
of stress at home on a child's cognitive development. In the medical literature, the Adverse Childhood Experiences (ACE) Study has shown that childhood struggles, like abuse, neglect, and other family dysfunction, influence a host of adult outcomes across physical, psychological, behavioral, and economic dimensions 7 This study affirms the importance of parental inputs but emphasizes that children from affluent families are also vulnerable to disruptions at home.

In the next section, I offer a more in-depth discussion of the relationship between family shocks and academic achievement. I describe the matched education and birth data sets in section 2 and go over descriptive results in section 3 to motivate my econometric model in section 4. In section 5. I present my results on family shocks and discuss the mechanisms that lead to changes in academic outcomes. Section [ concludes.

\section{From family shock to academic achievement}

In this section, I discuss the process by which a shock to the family environment could affect a student's performance at school. I address some of the challenges in establishing causation and the mechanisms that connect a family shock to academic achievement. Finally, I develop two hypotheses that explain why some children may be more vulnerable to family shocks than others.

The literature on specific family shocks has grappled with standard econometric problems related to establishing causation. There are many unobserved factors that could be correlated with certain family shocks and the academic performance. Stevens and Schaller (2011) employ child fixed effects, which control for inherited cognitive and noncognitive ability (among other things). Parental ability could also influence the propensity for job loss. Ananat, Gassman-Pines and Gibson-Davis (2011) use plant closings as an exogenous source of job loss. To study the effect of income shocks, some studies have considered changes to government transfers. Dahl and Lochner (2012)

\footnotetext{
${ }^{7}$ See Felitti et al. (1998) for an early overview. Also see the Center for Disease Control's webpage on the study: www.cdc.gov/violenceprevention/acestudy/.
} 
and Milligan and Stabile (2011) instrument benefits with predicted benefits during the transition to the Earned Income Tax Credit (EITC) and legislative variation in Canada, respectively. Duncan et al. (2011) use random assignment to antipoverty experiments to estimate the impact of income shocks on achievement. While my method for identifying the impact of family shocks does require a certain data structure, it does not rely on finding any special sources of variation.

In previous studies of specific family shocks, the process that links a family shock to educational outcomes is essentially a black box. While researchers can speculate about mechanisms, they have little to no evidence to support or refute their hypotheses. Part of the difficulty lies in the snowball nature of family shocks - rarely does one shock occur by itself. Take the example of parental job loss. When a parent loses his job (precipitating event), several other events (follow-on events) may occur simultaneously or shortly thereafter. Household income may drop, affecting the resources available to invest in the child's human capital. The unemployed parent may spend more time at home, potentially increasing his time investment in the child. There also may be some psychological stress associated with the job loss, which could affect a child's academic performance. After the parent loses his job, it is not clear which, if any, of these events would lead to a change in academic performance. It is also unclear which effects would dominate.

Here, I lump the precipitating event and all follow-on events under the term "family shock." While some might argue that I lose the link to the precipitating event, that link was never direct from the start. By reformulating the problem, I can analyze the net effect of a family shock without delving into the tangle of events that changed the home environment for a student.

Separate from the family shock as an event (or events) are all the changes in home inputs that occur as a result of or in reaction to the shock. For example, a family shock might affect the time that a student spends working on homework, reading, using a computer, or watching television; then any of these changes at home could go on to affect performance at school. While those are the time use variables available in my data set, we can think of each as a 
signal of what has changed in the home environment after a shock. Together, they shed light into the black box of mechanisms. With my reformulation, I am able to focus on how family shocks change inputs at home and then study the link between these mechansims and academic achievement.

The importance of family shocks and the mechanisms behind them need not be the same for all families. In fact, it is not clear from the outset which families might be more vulnerable to family shocks and why. One possibility is that disadvantaged students respond more to changes at home. Their parents may be less able to shield them from a negative shock by substituting other inputs. For example, an affluent family may have savings or extended family to rely on. When these parents have less money to buy books, they may take the time to check out books from the public library. Disadvantaged parents may be less able to make these substitutions, or they may already be in a corner solution where substitution is not an option. In this case, we would expect a one standard deviation change in family inputs to have a larger effect on low-SES students.

A second possibility is that affluent students are more vulnerable to family shocks. Their parents may be more involved in their learning initially, which could lead to bigger changes in home inputs after a family shock. Suppose affluent parents spend more time helping their children complete their homework. After a negative shock, the parents may not be able to devote as much time to this activity. If disadvantaged parents already do not spend much after-school time with their children, then parental involvement may not change much after a family shock. In a sense, affluent students may be more vulnerable because they have farther to fall.

The test score data lets me determine which types of students are more vulnerable to family shocks, and the time use data helps me understand why.

\section{Data}

The education data for this study is provided by the North Carolina Education Research Data Center (NCDERC). I present summary statistics in 
Table 1. These records cover all students in 3rd through 8th grade attending public school in North Carolina from 1997 to 2013. While test scores are available for all years, data on computer use and free reading was only collected 1999-2011, data on homework was collected through 2011, and data on TV watching was only collected through 2006. Since my econometric model requires a lagged outcome, I omit grade 3 and the first year an outcome was collected (1997 for test scores, homework, and TV watching, 1999 for computer use and free reading). These restrictions leave a sample of 8.3 million test score observations from 2.4 million students, though the sample size is less for the time use outcomes. The education data include other student demographics: sex, race/ethnicity, and subsidized lunch status. The North Carolina Department of Public Instruction (NCDPI) stopped requiring that schools report subsidized lunch status for individual students after 2006. Finally, each student-year record indicates the school attended.

The NCERDC matched students to the birth records of children born in North Carolina from 1987 onward. The North Carolina State Center for Health Statistics provided the raw birth record files. The match rate of student-year records to birth records for eligible students is $64 \%$ \% The birth records contain mother and father education, mother marital status, mother and father age, and other characteristics of the pregnancy and birth, such as alcohol and tobacco consumption. For births in 1988 or later, the NCERDC provided a unique mother identifier, which links the birth records and education records of siblings. The sample contains 723,362 unique mothers.

I make some adjustments to the outcome variables for ease of interpretation. The test scores are reported on a developmental scale that changed twice during the sample period. I normalize test scores to be mean zero, standard deviation one, by grade and year. In the raw data, the response options for the time use variables are given in ranges. In Appendix Table A.1, I report the original categorical responses, their frequencies, and the conversion scale. I convert the ranges to a continuous scale using the midpoint of the range. For

\footnotetext{
${ }^{8}$ Some students were not matched to birth records because of the years of available data. For example, a student in 8th grade in 1997 was likely born in 1982 or 1983.
} 
the top option, I use a value close to the lower bound. For analysis with the computer use variable, I condition on the student having a computer at home; i.e., I exclude an observation if the student indicates that his family does not own a computer. Similarly, I condition on whether the student reports that his teacher(s) assigned homework for the homework variable. For the main part of the analysis, I also standardized the time use variables by grade and year, as students' activities likely change as they age and as techonology changes over the years. The normalization facilitates comparison with test scores since all outcomes are in standard-deviation units.

Means and standard deviations for the time use variables before standardization are in Table1. In this sample, the average student uses a computer at home for school 3.5 days per month, reads in his free time 49 minutes per day, spends 2.5 hours per week on homework, and watches television 2.6 hours per day. I also report summary statistics for the sample matched to birth data and for the sample of student-year observations matched to a sibling in that year. I identify family shocks from this last subsample. While the matched sample mostly looks similar to the full sample, the sibling-pair sample appears to be negatively selected. In contrast to the mean-zero test scores for the full sample, the sibling-pair sample has a mean math score of -0.029 standard devations and a mean reading score of -0.065 standard deviations. The differences between the mean time use variables for the full sample and sibling-pair sample are equally or less substantial, relative to their standard deviations. Students in the sibling-pair sample spend less time using a computer for school, doing homework, and free reading, and more time watching television!9 The racial composition is overall similar across samples, though the matched sample is slightly less Hispanic. The rate of subsidized lunch eligibility is higher in the sibling-pair sample, indicating that these students are poorer. Since children from larger families tend to be poorer and have lower human capital, we would expect that students in the sibling-pair sample are negatively selected.

Finally, Table 1 gives summary statistics for variables only in the birth

\footnotetext{
${ }^{9}$ Before standardization, students in the sibling-pair sample appear to watch less TV. After I standardize by grade and year, we see that they watch more television.
} 
records. At the student-year observation level, the average mother was 26 years old at the time of the child's birth and had completed high school. Sixty-seven percent of mothers were married. The probability a student's mother was born outside of the U.S. is $6.1 \%$ in the matched sample but $5.2 \%$ in the sibling-pair sample. Since the NCERDC matched siblings through the mother, two siblings could in fact be half-siblings. Then the father information, if given, would not necessarily match. For $15 \%$ of observations in the siblingpair sample, no information on the father is present. For the rest, the average father was 29 years old at the time of birth and had completed high school. The sibling-pair sample averages are not notably different for these variables with one exception: There are fewer first borns in the sibling-pair sample since some first borns are only children.

\section{Descriptive results}

In this section, I discuss descriptive results for the outcomes and describe what they tell us about the relationship between the home environment and outcomes for different types of families.

In Table 2, I show that mean academic and time use outcomes vary substantially by family traits. The relationship between family background and achievement is well documented in the test score literature - stark differences exist by parents' educational attainment, income, and race. The estimated differences here are typical: The black-white test score gap is three-quarters of a standard deviation, and the difference in test scores between children with a mother who graduated college versus high school is similar.

I also observe variation in time use by family background, though these differences are less stark. I report all the time use results in standard deviation units. Homework time, free reading, and computer use are all increasing in mother's and father's education; TV watching decreases with parental education. The biggest spread between the children of high school educated and college educated mothers is in TV watching at 0.39 standard deviations, followed by homework time at 0.27 standard deviations, free reading at 0.15 
standard deviations, and computer use at 0.08 standard deviations. The other indicator of socioeconomic status, eligibility for subsidized lunch, follows the same pattern except for computer use. Poor families use a computer more days a month for school work, though the difference is small at 0.04 standard deviations. Children of black and Hispanic mothers also report higher frequencies of computer use relative to white mothers. They also spend less time on homework and free reading, and more time watching television.

Since the academic and time use outcomes are determined jointly, I examine the correlations between student-year outcomes to understand how they move together ${ }^{10}$ These results are in Table 3. I use standardized outcomes in the correlation tables, meaning all outcomes are measured relative to the distribution for a grade and year. First, math and reading scores are highly correlated with a correlation coefficient of 0.75 . Test scores are also positively related to homework time and free reading. Homework time is more strongly related to math scores $(0.20)$ relative to reading scores $(0.17)$, while the opposite is true for free reading, which correlates more highly with reading scores (0.22) than math scores $(0.15)$. These relationships suggest that math is a more homework-intensive subject, while a student can improve his reading skills by reading on his own. In contrast, the test scores are almost as negatively correlated with TV watching at -0.16 for both subjects. When students watch television, they may substitute away from more educationally enriching activities, like completing homework and reading. Finally, test scores are negatively correlated with computer use for school work, though this relationship is the weakest at -0.03 for math and -0.04 for reading. Although students ostensibly spend this time studying, more computer use could lead to lower test scores for several reasons. Students might get easily distracted by social media or other websites while they work on homework, or the learning they do on a computer could be less enriching than learning they do out of a book.

\footnotetext{
${ }^{10}$ Using the North Carolina data, Clotfelter, Ladd and Vigdor (2006) include the time use variables as regressors in value-added models of math and reading achievement. They find that achievement is generally increasing in homework time (but more so for math) and free reading time (but more so for reading). The patterns for computer use and TV watching are not monotonic.
} 
Table 3 also shows the correlations in how students spend their time. Free reading and homework time are the most highly correlated among these variables (0.14). These two variables are also negatively correlated with TV watching, which suggests that these activities may be substitutes. Given that time spent using a computer for school work is a subset of homework time, it is not surprising that these two variables are correlated. However, free reading and computer use are also positively correlated, though they correlate in different directions with test scores. These descriptives indicate that the relationship between computer use and test scores may not be straightforward.

Next, I calculate the correlations between own outcomes and sibling outcomes and present the results in Table 4. Each sibling-year pair represents one observation. These correlations give insight into the relationship between family environment and academic and time use outcomes. In general, the sibling correlations have the same sign as, but a lower magnitude than, the own outcome correlations. The correlation between own math score and sibling math score, as well as own reading score and sibling reading score, is close to 0.5 . This correlation is the first evidence in this paper that characteristics shared within a family, whether genetics, permanent inputs, or transitory inputs, influence achievement. The rest of the diagonal shows the within-family correlations of time use outcomes. The association for TV watching is especially strong at 0.21 , relative to the other time use variables. Television sets often function as a public good within a household, and siblings may watch TV together. TV watching by one child may even distract his sibling from other activities. In fact, sibling television use is just as closely correlated with outcomes as own television use.

In Table 5, I examine whether the relationship between achievement and time use varies by family characteristics. In other words, I examine whether these correlations are uniformly positive or negative for all family types, as well as whether they are equally strong across families. I arrange family traits from least to most advantaged. Although computer use and achievement are negatively correlated for most families, they have a small, positive correlation for the most affluent families (parent went to graduate school, mother is white). 
Furthermore, the correlations are increasing in socioeconomic status, meaning that computer use is the most negatively associated with achievement in the least affluent families (parent dropped out of high school, student eligible for subsidized lunch). The pattern suggests that the context of computer use is key. Affluent parents may be better able to monitor computer use, or homework activities on the computer may be more effective for children of these parents.

Another activity that appears highly contextual is TV watching. The achievement of children of black mothers is positively correlated with time spent watching televsion, while it is negatively correlated for all other groups shown. For other less affluent groups (children eligible for subsidized lunch, with a Hispanic mother, or with a high school dropout parent), the correlation is negative but relatively close to zero. Again, the correlation patterns between TV watching and achievement are monotonic in socioeconomic status. They are also consistent with the mainstreaming hypothesis, which contends that low-SES children receive more cognitive stimulation from watching TV than they would otherwise. Among high-SES children, the opposite is true, so high levels of TV viewing is especially detrimental for these students (Morgan and Gross, 1980).

Finally, for time spent free reading and on homework, the intensity of the relationship between these activities and achievement varies by demographics. The correlation between homework time and test scores is almost uniformly increasing in socioeconomic status; however, the evidence for free reading is mixed. For math, the correlation between free reading and test scores is higher for low-SES students. There is no clear pattern for reading test scores, and all the correlations by family characteristics are clustered around the overall correlation. These estimates suggest that time spent free reading is equally productive for all types of students. For disadvantaged students, poor reading skills could inhibit performance in math, making the time they spend improving their reading comprehension especially beneficial. This evidence suggests that the mechanism through which family inputs affect achievement is not the same for all families. 
Several stylized facts emerge from this descriptive analysis. One, student achievement is positively correlated with homework time and free reading time, negatively correlated with TV time, and barely correlated with computer time for school work. Two, there are relatively strong within-family correlations in test scores and TV watching. Three, the correlation between achievement and time use depends on family background. Even the signs of the correlations for computer use and TV watching depend on family characteristics. For all time use outcomes, the strength of the association depends on socioeconomic status of the family. And four, the outcomes themselves vary by family background, though not as much for time use outcomes as for academic ones. Students from high-SES families generally score better on tests, spend more time free reading and on homework, and spend less time watching television. The evidence on the relationship between computer use and affluence is mixed.

While this descriptive analysis establishes basic relationships between outcomes and student demographics, it only hints at how these variables may co-move within a family. Within-family correlations pick up permanent family characteristics as well as transitory ones. My econometric model identifies the impact that family shocks have on outcomes so that I can analyze how and why changes at home affect achievement.

\section{Econometric model}

\subsection{Test score production}

I adopt a model of test score production that is common in this literature:

$$
y_{i f s t}=\gamma y_{i t-1}+x_{i} \beta+\delta_{s t}+\varepsilon_{i f s t}
$$

where $y_{i f s t}$ is the test score for student $i$ from family $f$ attending the schoolgrade pair $s$ in year $t$. This year's test score is a function of last year's test score $y_{i t-1}$, individual characteristics $x_{i}$, a school-grade-year fixed effect $\delta_{s t}$, and an idiosyncratic error $\varepsilon_{i f s t}$. In the teacher quality literature, this specification is often called a value-added model since controlling for the previous year's score 
isolates the teacher's contribution from other factors known to predict test scores. Next, I decompose the idiosyncratic shock into a family-year-specific component, or family shock, and an error.

$$
\varepsilon_{i f s t}=\xi_{f t}+\nu_{i f s t}
$$

Like other papers in the test score literature, I take the lagged test score as a sufficient statistic for all previous inputs as well as endowed ability. Many other studies have developed the assumptions inherent in the lagged test score specification; Todd and Wolpin (2003) have perhaps the most thorough discussion. Importantly for this paper, the lagged test contains the previous year's family shock. In other words, the lagged score fully captures the effects of any past family shocks on the current year's test score. I also assume that the effects of inputs and ability, including the family shock, all decay at a constant rate $\gamma$. These assumptions are standard in the test score production literature 11

The school-grade-year fixed effects control for unobserved variation across schools, within a school over time, and within different grades in the same school. They also control for other geographical and temporal variation, such as neighborhood characteristics and local labor market conditions. Including the grade component of these fixed effects is important because siblings often attend the same school at the same time. Without it, a school shock might confound the estimate of a family shock 12

To estimate equation 1. I assume that the idiosyncratic shock $\varepsilon_{\text {ifst }}$ is orthogonal to the regressors $y_{i t-1}, x_{i}$, and $\delta_{s t}$. The family shock is one component of the total shock to a student's test score in a year and thus must also be orthogonal to the regressors. This assumption is key for identification of the family shock parameters. For the interpretation of $\xi_{f t}$ as a family shock to

\footnotetext{
${ }^{11}$ See Clotfelter et al. (2006), Todd and Wolpin (2007), Aaronson et al. (2007), and Chetty et al. (2014a) for examples of similar specifications.

${ }^{12}$ Note that school shocks could still confound the estimate of a family shock when siblings are in the same grade at the same school. This possibility arises for twins or multiples; however, non-singletons only make up $1.4 \%$ of the sample.
} 
hold, it must not be contaminated by any other transitory trait that is shared by siblings but occurs outside of the family. For example, if siblings had the same math teacher, the estimate of the family shock parameter could reflect their teacher's value-added in addition to the family shock.

\subsection{Application to time use outcomes}

I use the same specification (equation 1) and error decomposition (equation 2) for the time use outcomes as for the test score outcomes. With the same model, the results for academic outcomes and time use outcomes are easier to compare. However, the interpretation of the parameters changes. While the lagged test score controls for ability and past inputs, the lagged outcome for time use variables controls for habit persistence. With both types of outcomes, the interpretation of the family shock is as an unexpected change in the outcome that is shared by siblings. The school-grade-year fixed effects still control for geographical and temporal trends, which could still include school characteristics (e.g., teachers' propensity to assign large amounts of homework) but might also include trends in technology adoption (in the case of the computer use outcome).

\subsection{Calculation of the variation in family shocks}

The parameter of interest in the paper is the standard deviation of $\xi_{f t}$. It measures the effect of a one standard deviation family shock on an outcome. Since the estimates of the $\xi_{f t}$ come from a small number of observations, computation with the traditional variance formula introduces a substantial amount of estimation error. Instead, I create a sample of sibling pairs and compute the covariance of residuals for siblings in the same year.

$$
\operatorname{Cov}\left(\varepsilon_{i f s t}, \varepsilon_{i^{\prime} f s^{\prime} t}\right) \text { for } i \neq i^{\prime}
$$

The variance of the family shock is equal to the covariance of residuals for sibling-year pairs as long as the family shock is uncorrelated with the error, i.e. 
$\operatorname{Cov}\left(\xi_{f t}, \nu_{i f s t}\right)=0$, and the errors for sibilings in the same year are unrelated, i.e. $\operatorname{Cov}\left(\nu_{i f s t}, \nu_{i^{\prime} f s^{\prime} t}\right)=0$ for $i \neq i^{\prime}$. I report the variation in family shocks as a standard deviation for ease of interpretation.

\section{$5 \quad$ Family shock results}

In this section, I briefly summarize the regression results before presenting my main results on the impact of family shocks on academic achievement and time use outcomes. I also discuss the relative importance of family shocks on different outcomes and how family shocks are related across outcomes.

\subsection{Regression results}

I present results from the outcome regressions in Table 6. Estimates from the test score models in columns 1 and 2 will be familiar to many readers. All coefficients have the expected sign, with the exception of alcohol consumption during pregnancy. The coefficients for parents' education and race/ethnicity are generally larger in magnitude than the estimates in Clotfelter et al. (2006), which uses a similar specification to study the impact of teacher characteristics on achievement. The estimated effects of lagged score are also typical.

Perhaps less familiar with readers are the results for the time use outcomes, which are in columns 3-6. All outcomes are in standard-deviation units, normalized by grade and year. Habit persistence is highest for free reading and TV watching at 0.4 standard deviations; the corresponding coefficients for computer use and homework time are about half of that. The patterns of coefficients for mother's and father's education and race/ethnicity generally follow the same pattern as the differences in means, though the marginal differences are much smaller. The biggest differences occur between black and white children, particularly for time spent watching television. For homework time, free reading, and TV watching, most estimates for the parent education categories are less than 0.1 standard deviations in magnitude. For computer use, they are all within 0.03 standard deviations. 


\subsection{Family shock results}

The family shock results are in Table 7. To generate these estimates, I take the residuals from the test score model and calculate the covariance for sibling-year pairs. I present the results in standard-deviation units.

I find that the net impact of a family shock is 0.13 standard deviations on math scores and 0.15 standard deviations on reading scores. For context, Chetty et al. (2014a) find that teacher value-added is 0.14 standard devations in math and 0.1 standard deviations in English. Like Chetty et al. (2014a), I use a value-added specification, which facilitates the comparison. Thus, a one standard devation change in the family inputs has close to the same impact on math scores as a one standard deviation change in teacher quality. For reading scores, the impact of a one standard deviation change in family environment is $50 \%$ larger than a one standard deviation change in teacher quality.

Turning to the family shock results by demographics, I can evaluate the two hypotheses on why the same size family shock might have a larger impact on some families than others. One possibility is that children from disadvantaged families are more vulnerable to family shocks. Their parents may be less able to insure against shocks, or they might be less able to substitute other inputs. Another possibility is that children from advantaged families are more vulnerable. If their parents spend a lot of time with them, making their achievement production process more family intensive, they might suffer more with a change in the family environment. If the parents were less involved from the outset, there is less scope for family changes to affect learning.

In math, the impact of a family shock is increasing in affluence, whether measured by mother's education, father's education ${ }^{13}$ or subsidized lunch status. Because of the large sample size, almost all of these differences are statistically significant. As an example, compare children with mothers that dropped out of high school to children with mothers that completed college: The ef-

\footnotetext{
${ }^{13}$ I only calculate these statistics for siblings with the same level of father's education. When it differs, the children are more likely to be half-siblings. Even when it is the same, the children could still be half-siblings. Regardless, the interpretation is more clear when siblings have the same level of father's education, whether their fathers are different or not.
} 
fect of a one standard deviation family shock on the math scores is about 15\% larger if the child's mother finished college. Parents' education and income are the more straightforward measures of socioeconomic status. For other family characteristics, the patterns still generally support the same hypothesis. Family shocks have a larger impact on children of married mothers, where mother's marital status is measured at birth 14 They are also larger for children with white mothers compared to black mothers, but they are largest for children of Hispanic mothers. The difference between children of white mothers and Hispanic mothers is likely driven by mother's nativity since children of immigrant mothers are more vulnerable to family shocks compared to native mothers. Although immigrant mothers may appear to have a lower socioeconomic status, the patterns here may still be consistent with the same hypothesis. Immigrant parents may have higher educational aspirations for their children and invest more time in their child's development, rendering them more like well-educated or richer parents in how they respond to a family shock. By and large, the evidence for math scores is consistent with the hypothesis that family shocks have a bigger effect on children from affluent families.

For reading scores, the evidence is mixed. There is no consistent relationship between family shock impacts and parents' education. Poor students are more vulnerable to family shocks, and the impacts for children of black mothers and children of white mothers are the same. Children of Hispanic mothers and children of immigrant mothers are relatively more susceptible to family shocks. Children of single mothers are also relatively more susceptible.

Comparing the math and reading results, we see differences in both the magnitude of the effects (intercept) and how the vary across socioeconomic status (slope). The impact of a family shock on reading scores is generally higher than the impact on math scores. These results are in line with the idea that math scores are determined more at school and reading scores are determined more at home. However, this story is more true for the children with parents with low levels of education. For children with highly educated

\footnotetext{
${ }^{14}$ In calculating these statisitics, I condition on mothers having the same marital status at the birth of both children.
} 
parents, the impact of a family shock on math scores and on reading scores is more similar. This pattern could arise if highly educated parents have a higher math ability themselves and are better equipped to help their children with their math homework.

Overall, these results offer more support for the hypothesis that family shocks have a bigger impact on children with affluent parents. However, the test score results alone give little indication of the mechanisms that translate disruptive family events into changes in achievement. For this, I turn to the results for the time use variables.

From the top row of Table 7, family shocks have a larger effect on students' time use than test scores when I compare all outcomes in standard-deviation units. In contrast to the 0.13 effect in math and 0.15 effect in reading, a one standard deviation family shock moves homework use by 0.14 standard deviations ( 0.33 hours per week), free reading by 0.20 standard deviations ( 0.12 hours per day), computer use for school work by 0.18 standard deviations (1.07 days per month), and TV watching by 0.25 standard deviations ( 0.50 hours per day).

Examining these results by demographics, we see that the impact of a family shock on free reading and homework increases with the family's socioeconomic status. The relationship between mother's education and the effect of a family shock on homework time is particularly striking. In response to a one standard deviation family shock, a student with a mother that dropped out of high school only sees his homework time change by 0.09 standard deviations (0.21 hours per week). However, a student with a mom that went to graduate school sees his homework time change by 0.20 standard deviations ( 0.49 hours per week). The same patterns observed for math scores hold up for homework time and free reading, but the differences for the time use variables are larger.

Going back to the process of family shock to academic achievement, it seems that first a family shock affects how much time a child spends on educationally enriching activities at home, like homework and reading for pleasure. When the parents are more affluent, the family shock has a bigger impact on these activities. Then, these changes in time use at home, and likely other 
family inputs that are positively related to learning, go on to impact achievement. However, since achievement is a function of family inputs and school inputs, and the school inputs are held constant, the effect of the family shock on achievement is lessened but still present.

In contrast to the free reading and homework time variables, the pattern for the effect of family shocks on TV watching and computer use is mixed. Recall that these variables are negatively correlated with achievement. The impact of a family shock on computer use is often increasing in parents' education but is decreasing in income as measured by subsidized lunch eligibility. The impact of a family shock on TV watching is more often decreasing in affluence. The differences by socioeconomic status are also smaller for these variables. For example, the range of impacts by mother's education is 0.02 standard deviations for both of these variables, while it is 0.12 standard deviations for homework time. While family shocks have a large impact on TV time, they seem to affect all children's TV time about equally. The same is not true for the educational activities.

We can learn more about the relationship between test scores and the family shock mechanisms by analyzing the correlations between family shocks to achievement and family shocks to time use. Similar to my calculation of the variation in family shocks, I modify the traditional correlation formula. Let $k$ and $\ell$ represent two different outcomes. Normally, the formula to find the correlation in family shocks to these two different outcomes would be

$$
\operatorname{Corr}\left(\xi_{f t}^{k}, \xi_{f t}^{\ell}\right)=\frac{\operatorname{Cov}\left(\xi_{f t}^{k}, \xi_{f t}^{\ell}\right)}{\sqrt{\operatorname{Var}\left(\xi_{f t}^{k}\right) \operatorname{Var}\left(\xi_{f t}^{\ell}\right)}}
$$

I replace both variances in the denominator with the covariance of sibling residuals, which is the same modification I made to calculate the variation in family shocks. I replace the numerator with covariance of sibling residuals for different outcomes, i.e. $\operatorname{Cov}\left(\varepsilon_{i f s t}^{k}, \varepsilon_{i^{\prime} f s^{\prime} t}^{\ell}\right)$ for $i \neq i^{\prime}$. For this substitution to be valid, the family shock to one outcome must be uncorrelated with the individual error for any other outcome, i.e. $\operatorname{Cov}\left(\xi_{f t}^{k}, \nu_{i f s t}^{\ell}\right)=0$, and the siblings' individual 
errors for different outcomes must also be unrelated, i.e. $\operatorname{Cov}\left(\nu_{i f s t}^{k}, \nu_{i^{\prime} f s^{\prime} t}^{\ell}\right)=0$ for $i \neq i^{\prime}$.

Table 8 reports results on the correlations between family shocks to different outcomes. The correlation between family shocks to math achievement and family shocks to reading achievement is 0.82 , indicating that family disruptions have a similar effect on a student's cognitive development across subjects. I also find a positive relationship between family shocks to achievement and family shocks to educational time use. This means that a family shock that increases homework time or free reading time also increases test scores. The relationship between family shocks to free reading and family shocks to reading scores $(\rho=0.34)$ is stronger than the relationship between family shocks to free reading and family shocks to math scores $(\rho=0.22)$. Conversely, family shocks to homework time are more strongly associated with family shocks to math scores $(\rho=0.33)$ compared to reading scores $(\rho=0.28)$.

Turning to the relationship between family shocks to achievement and family shocks to non-educational time use, we see that the magnitudes are all lower compared to the correlations with educational uses of time. These correlations are also also all negative, ranging from -0.06 to -0.12 . The correlations between family shocks to different uses of time are generally weak, with the exception of free reading and homework time.

Let us return to the process through which a family shock affects academic achievement. Of the various potential mechanisms, educational time use appears to be the most important. The evidence suggests that family shocks that change the time a student spends on educational activities (like free reading and homework) are the ones that have a bigger impact on the student's learning. These results also help us understand why family shocks have a bigger impact on children from affluent families. In the face of a family shock, the larger changes in free reading and homework time for these children likely cause the larger changes in test scores. 


\section{Conclusion}

In this paper, I estimate a model of test score production and analyze the family-year-specific component of the residual to determine the impact of family shocks on student test scores. I find that a one standard deviation family shock moves math scores by 0.13 standard deviations and reading scores by 0.15 standard deviations. These estimates are similar in magnitude to recent estimates of the effect of having a one standard deviation better teacher (Chetty et al. 2014a). Chetty, Friedman and Rockoff's (2014b) estimate on the long-term impact of teacher effectiveness offers some insight on how a yearlong change to a student's inputs translates into later life outcomes ${ }^{15}$ They determine that a one standard deviation improvement in teacher quality increases lifetime income by almost $\$ 40,000$. While recent work in the economics of education has sought to understand which school interventions are most effective and why, here I emphasize the importance of the family side of achievement production. Transitory family characteristics, in addition to permanent family characteristics, influence student learning.

The second contribution of this paper is to determine which families are more vulnerable to family shocks, and why. A same-size family shock has a larger impact on students from affluent families, likely because these parents are initially more involved in their children's learning. These results suggest that successful home interventions are ones that help parents guide their children to educationally enriching activities. They also support the idea that school interventions are most helpful to disadvantaged students - changes to affluent students' achivement more often come from changes at home. However, schools can still play an important role in mitigating the negative effects of family shocks.

This paper represents a first step in understanding the relationship between family shocks and academic outcomes, and several unanswered questions remain. First, much of the evidence in this paper comes from correlations. For

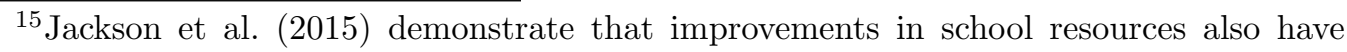
long-run effects.
} 
example, I look to the correlation between the effect of a family shock on free reading time and the effect of a family shock on reading test scores to understand the relationship between the time use mechanism and the outcome. Future work on this topic must ascertain the direct causal link between various mechanisms and outcomes. The data in this paper is not well-suited to address this issue since all outcomes are measured simultaneously. A second question of interest is whether family shocks are more important at certain ages. Is the cognitive ability of younger children more sensitive to changes in parental investments, as found Cunha, Heckman and Schennach (2010)? My framework cannot answer this question directly since I use sibling pairs to calculate the impact of family shocks, and siblings are almost always different ages. A final issue is the persistence of family shocks. Do children bounce back quickly after a family shock, or does the impact of the shock carry through to adulthood? In the teacher value-added literature, teacher effects fade out quickly when persistence is evaluated in terms of future years' scores (Kane and Staiger, 2008; Rothstein, 2010). However, Chetty et al. (2014b) find that teacher value-added impacts a host of later life outcomes including college attendance, teenage pregnancy, and earnings. Thus, there may be scope for a family shock in a single year to reverberate throughout the life cycle. 


\section{References}

Aaronson, Daniel, Lisa Barrow, and William Sander, "Teachers and Student Achievement in the Chicago Public High Schools," Journal of Labor Economics, 2007, 25 (1), 95-135.

Amato, Paul R., "Children of Divorce in the 1990s: An Update of the Amato \& Keith (1991) Meta-Analysis," Journal of Family Psychology, 2001, 15 (3), $355-70$.

_ and Bruce Keith, "Parental Divorce and the Well-Being of Chidren: A Meta-Analysis," Psychological Bulletin, 1991, 110 (3), 26-46.

Ananat, Elizabeth O., Anna Gassman-Pines, and Christina M. Gibson-Davis, "The effect of local employment losses on childen's educational achievement," in Greg J. Duncan and Richard J. Murnane, eds., Whither Opportunity? Rising Inequality and the Uncertain Life Chances of Low-Income Children, New York: Russel Sage Publications, 2011, pp. 299314.

Björklund, Anders and Kjell G. Salvanes, "Education and Family Background: Mechanisms and Policies," in Eric A. Hanushek, Stephen Machin, and Ludger Woessman, eds., Handbook of the Economics of Education, Vol. 3, Amsterdam: Elsevier, 2011, pp. 201-47.

Chetty, Raj, John N. Friedman, and Jonah E. Rockoff, "Measuring the Impacts of Teachers I: Evaluating Bias in Teacher Value-Added Estimates," American Economic Review, 2014, 104 (9), 2593-2632.

$\ldots, \ldots$, and _ , "Measuring the Impacts of Teachers II: Teacher Value-Added and Student Outcomes in Adulthood," American Economic Review, 2014, 104 (9), 2633-79.

Clotfelter, Charles T., Helen F. Ladd, and Jacob L. Vigdor, "TeacherStudent Matching and the Assessment of Teacher Effectiveness," Journal of Human Resources, 2006, 41 (4), 778-820. 
Cunha, Flavio, James J. Heckman, and Susanne M. Schennach, "Estimating the Technology of Cognitive and Noncognitive Skill Formation," Econometrica, 2010, 78 (3), 883-931.

Dahl, Gordon B. and Lance Lochner, "The Impact of Family Income on Child Achievement: Evidence from the Earned Income Tax Credit," American Economic Review, 2012, 102 (5), 1927-56.

Duncan, Greg J., Pamela A. Morris, and Chris Rodrigues, "Does Money Really Matter? Estimating Impacts of Family Income on Young Children's Achievement With Data From Random-Assignment Experiments," Developmental Psychology, 2011, 47 (5), 1263-79.

Felitti, Vincent J., Robert F. Anda, Dale Nordenberg, David F. Williamson, Alison M. Spitz, Valerie Edwards, Mary P. Koss, and James S. Marks, "Relationship of Childhood Abuse and Household Dysfunction to Many of the Leading Causes of Death in Adults: The Adverse Childhood Experiences (ACE) Study," American Journal of Preventative Medicine, 1998, 14 (4), 245-58.

Figlio, David, Jonathan Guryan, Krzysztof Karbownik, and Jeffrey Roth, "The Effects of Poor Neonatal Health on Children's Cognitive Development," American Economic Review, 2014, 104 (12), 3921-55.

Fiorini, Mario and Michael P. Keane, "How the Allocation of Children's Time Affects Cognitive and Noncognitive Development," Journal of Labor Economics, 2014, 32 (4), 787-836.

Hanushek, Eric, "Teacher Characteristics and Gains in Student Achievement: Estimation Using Micro Data," American Economic Review, 1971, $61(2), 280-88$.

Jackson, C. Kirabo, Rucker C. Johnson, and Claudia Persico, "The Effects of School Spending on Educational and Economic Outcomes: Evidence from School Finance Reforms," 2015. NBER Working Paper 20847. 
Kalil, Ariel and Kathleen M. Ziol-Guest, "Parental employment circumstances and children's academic progress," Social Science Research, 2008, 37, 500-15.

Kane, Thomas J. and Douglas O. Staiger, "Estimating Teacher Impacts on Student Achievement: An Experimental Evaluation," 2008. NBER Working Paper 14607.

_, Jonah E. Rockoff, and Douglas O. Staiger, "What does certification tell us about teacher effectiveness? Evidence from New York City," Economics of Education Review, 2008, 27, 615-31.

Krueger, Alan B., "Experimental Estimates of Education Production Functions," Quarterly Journal of Economics, 1999, 114 (2), 497-532.

Milligan, Kevin and Mark Stabile, "Do Child Tax Benefits Affect the Well-being of Children? Evidence from Canadian Child Benefit Expansions," American Economic Journal: Economic Policy, 2011, 3 (3), 175205.

Morgan, Michael and Larry Gross, "Television Viewing, IQ and Academic Achievement," Journal of Broadcasting, 1980, 24 (2), 117-33.

Murnane, Richard J., The Impact of School Resources on the Learning of Inner City Children, Cambridge, MA: Ballinger Publishing, 1975.

Neal, Derek, "The Effects of Catholic Secondary Schooling on Educational Achievement," Journal of Labor Economics, 1997, 15 (1), 98-123.

Rivkin, Steven G., Eric A. Hanushek, and John F. Kain, "Teachers, Schools, and Academic Achievement," Econometrica, 2005, 73 (2), 417-58.

Rockoff, Jonah E., "The Impact of Individual Teachers on Student Achievement: Evidence from Panel Data," American Economic Review, 2004, 94 (2), 247-52. 
Rothstein, Jesse, "Teacher Quality in Educational Production: Tracking, Decay, and Student Achievement," Quarterly Journal of Economics, 2010, $125(1), 175-214$.

_ , "Revisiting the Impacts of Teachers," 2014. Working paper.

Stevens, Ann Huff and Jessamyn Schaller, "Short-run effects of parental job loss on children's academic achievement," Economics of Education Review, 2011, 30, 289-99.

Tillman, Kathryn Harker, "Family Structure Pathways and Academic Disdavantage among Adolescents in Stepfamilies," Sociological Inquiry, 2007, 77 (3), 383-424.

Todd, Petra E. and Kenneth I. Wolpin, "On the Specification and Estimation of the Production Function for Cognitive Achievement," Economic Journal, 2003, 113 (485), F3-F33.

_ and _, "The Production of Cognitive Achievement in Children: Home, School, and Racial Test Score Gaps," Journal of Human Capital, 2007, 1 (1), 91-136. 
Table 1: Descriptive statistics

\begin{tabular}{|c|c|c|c|c|c|c|}
\hline Sample: & \multicolumn{2}{|c|}{ Full } & \multicolumn{2}{|c|}{ Matched } & \multicolumn{2}{|c|}{ Sibling-pair } \\
\hline Student-year observations & \multicolumn{2}{|c|}{$8,301,355$} & \multicolumn{2}{|c|}{$4,890,464$} & \multicolumn{2}{|c|}{$1,426,970$} \\
\hline Unique students & \multicolumn{2}{|c|}{$2,403,870$} & \multicolumn{2}{|c|}{$1,200,317$} & \multicolumn{2}{|c|}{549,989} \\
\hline Unique schools & \multicolumn{2}{|c|}{2,255} & \multicolumn{2}{|c|}{2,244} & \multicolumn{2}{|c|}{2,211} \\
\hline $\begin{array}{l}\text { Match rate to birth data } \\
\text { for eligible observations }\end{array}$ & \multirow{2}{*}{\multicolumn{2}{|c|}{0.642}} & & & & \\
\hline Unique mothers & & & \multicolumn{2}{|c|}{723,362} & \multicolumn{2}{|c|}{236,881} \\
\hline Math score (std devs) & 0 & (1) & -0.009 & $(0.988)$ & -0.029 & $(1.007)$ \\
\hline Reading score (std devs) & 0 & (1) & -0.012 & $(0.988)$ & -0.065 & $(1.007)$ \\
\hline Homework (std devs) & 0 & (1) & -0.012 & $(0.990)$ & -0.028 & $(0.988)$ \\
\hline Free reading (std devs) & 0 & (1) & -0.045 & $(0.969)$ & -0.058 & $(0.968)$ \\
\hline Computer use (std devs) & 0 & (1) & -0.025 & $(0.978)$ & -0.033 & $(0.970)$ \\
\hline TV watching (std devs) & 0 & (1) & 0.022 & $(1.002)$ & 0.010 & $(1.016)$ \\
\hline Homework (hrs/wk) & 2.53 & $(2.42)$ & 2.49 & $(2.41)$ & 2.44 & $(2.39)$ \\
\hline Free reading (hrs/day) & 0.81 & $(0.62)$ & 0.78 & $(0.60)$ & 0.77 & $(0.60)$ \\
\hline Computer use (days/mo) & 3.47 & $(6.29)$ & 3.26 & $(6.09)$ & 3.17 & $(5.99)$ \\
\hline TV watching (hrs/day) & 2.57 & $(1.99)$ & 2.56 & $(2.00)$ & 2.53 & $(2.02)$ \\
\hline White & 0.580 & & 0.611 & & 0.597 & \\
\hline Black & 0.281 & & 0.297 & & 0.311 & \\
\hline Hispanic & 0.078 & & 0.040 & & 0.035 & \\
\hline Other race & 0.035 & & 0.028 & & 0.030 & \\
\hline Multiracial & 0.025 & & 0.024 & & 0.027 & \\
\hline Female & 0.493 & & 0.497 & & 0.497 & \\
\hline Subsidized lunch & 0.435 & & 0.429 & & 0.511 & \\
\hline Mother education & & & 12.6 & $(2.4)$ & 12.6 & $(2.5)$ \\
\hline Mother age & & & 25.9 & $(5.9)$ & 25.3 & $(5.6)$ \\
\hline Mother married & & & 0.670 & & 0.665 & \\
\hline Mother immigrant & & & 0.061 & & 0.052 & \\
\hline No father information & & & 0.133 & & 0.150 & \\
\hline Father education & & & 12.7 & $(2.4)$ & 12.8 & $(2.5)$ \\
\hline Father age & & & 28.9 & $(6.5)$ & 28.5 & $(6.3)$ \\
\hline Father immigrant & & & 0.073 & & 0.069 & \\
\hline First born & & & 0.441 & & 0.323 & \\
\hline Birth weight & & & 7.31 & $(1.31)$ & 7.20 & $(1.38)$ \\
\hline Alcohol when pregnant & & & 0.014 & & 0.013 & \\
\hline Tobacco when pregnant & & & 0.179 & & 0.177 & \\
\hline
\end{tabular}

Sources: North Carolina Education Research Data Center and North Carolina State Center for Health Statistics. Sample: Students in grades 4-8, years 1998-2013. Standard deviations in parentheses. 
Table 2: Mean outcomes by demographics

\begin{tabular}{|c|c|c|c|c|c|c|}
\hline & $\begin{array}{l}\text { Math } \\
\text { score }\end{array}$ & $\begin{array}{c}\text { Reading } \\
\text { score }\end{array}$ & Homework & $\begin{array}{c}\text { Free } \\
\text { reading }\end{array}$ & $\begin{array}{c}\text { Computer } \\
\text { use }\end{array}$ & $\begin{array}{c}\text { TV } \\
\text { watching }\end{array}$ \\
\hline$\overline{\text { All }}$ & $\begin{array}{l}-0.009 \\
(0.988)\end{array}$ & $\begin{array}{l}-0.012 \\
(0.988)\end{array}$ & $\begin{array}{l}-0.012 \\
(0.990)\end{array}$ & $\begin{array}{l}-0.045 \\
(0.969)\end{array}$ & $\begin{array}{l}-0.025 \\
(0.978)\end{array}$ & $\begin{array}{c}0.022 \\
(1.002)\end{array}$ \\
\hline \multicolumn{7}{|c|}{ Mother's education } \\
\hline$<$ high school & $\begin{array}{l}-0.475 \\
(0.873)\end{array}$ & $\begin{array}{l}-0.492 \\
(0.927)\end{array}$ & $\begin{array}{l}-0.137 \\
(0.938)\end{array}$ & $\begin{array}{l}-0.123 \\
(0.957)\end{array}$ & $\begin{array}{l}-0.040 \\
(1.022)\end{array}$ & $\begin{array}{c}0.134 \\
(1.061)\end{array}$ \\
\hline High school & $\begin{array}{l}-0.168 \\
(0.914)\end{array}$ & $\begin{array}{l}-0.155 \\
(0.932)\end{array}$ & $\begin{array}{l}-0.070 \\
(0.954)\end{array}$ & $\begin{array}{l}-0.087 \\
(0.956)\end{array}$ & $\begin{array}{l}-0.051 \\
(0.974)\end{array}$ & $\begin{array}{c}0.107 \\
(1.021)\end{array}$ \\
\hline Some college & $\begin{array}{c}0.164 \\
(0.917)\end{array}$ & $\begin{array}{c}0.179 \\
(0.899)\end{array}$ & $\begin{array}{c}0.034 \\
(0.997)\end{array}$ & $\begin{array}{l}-0.011 \\
(0.975)\end{array}$ & $\begin{array}{l}-0.032 \\
(0.951)\end{array}$ & $\begin{array}{l}-0.018 \\
(0.958)\end{array}$ \\
\hline College & $\begin{array}{c}0.673 \\
(0.895)\end{array}$ & $\begin{array}{c}0.629 \\
(0.834)\end{array}$ & $\begin{array}{c}0.196 \\
(1.065)\end{array}$ & $\begin{array}{c}0.066 \\
(0.973)\end{array}$ & $\begin{array}{c}0.033 \\
(0.959)\end{array}$ & $\begin{array}{l}-0.287 \\
(0.836)\end{array}$ \\
\hline Grad school & $\begin{array}{c}0.859 \\
(0.882)\end{array}$ & $\begin{array}{c}0.815 \\
(0.815)\end{array}$ & $\begin{array}{c}0.257 \\
(1.099)\end{array}$ & $\begin{array}{c}0.179 \\
(1.016)\end{array}$ & $\begin{array}{c}0.077 \\
(0.991)\end{array}$ & $\begin{array}{l}-0.408 \\
(0.785)\end{array}$ \\
\hline \multicolumn{7}{|l|}{ Father's education } \\
\hline Missing & $\begin{array}{l}-0.537 \\
(0.867)\end{array}$ & $\begin{array}{l}-0.521 \\
(0.922)\end{array}$ & $\begin{array}{l}-0.146 \\
(0.935)\end{array}$ & $\begin{array}{l}-0.123 \\
(0.965)\end{array}$ & $\begin{array}{c}0.021 \\
(1.089)\end{array}$ & $\begin{array}{c}0.317 \\
(1.117)\end{array}$ \\
\hline$<$ high school & $\begin{array}{l}-0.335 \\
(0.876)\end{array}$ & $\begin{array}{l}-0.362 \\
(0.925)\end{array}$ & $\begin{array}{l}-0.115 \\
(0.942)\end{array}$ & $\begin{array}{l}-0.115 \\
(0.952)\end{array}$ & $\begin{array}{l}-0.079 \\
(0.965)\end{array}$ & $\begin{array}{c}0.058 \\
(1.008)\end{array}$ \\
\hline High school & $\begin{array}{l}-0.060 \\
(0.911)\end{array}$ & $\begin{array}{l}-0.047 \\
(0.921)\end{array}$ & $\begin{array}{l}-0.044 \\
(0.963)\end{array}$ & $\begin{array}{l}-0.074 \\
(0.956)\end{array}$ & $\begin{array}{l}-0.063 \\
(0.947)\end{array}$ & $\begin{array}{c}0.046 \\
(0.988)\end{array}$ \\
\hline Some college & $\begin{array}{c}0.267 \\
(0.906)\end{array}$ & $\begin{array}{c}0.277 \\
(0.881)\end{array}$ & $\begin{array}{c}0.061 \\
(1.006)\end{array}$ & $\begin{array}{c}0.016 \\
(0.983)\end{array}$ & $\begin{array}{l}-0.036 \\
(0.934)\end{array}$ & $\begin{array}{c}-0.081 \\
(0.920)\end{array}$ \\
\hline College & $\begin{array}{c}0.700 \\
(0.882)\end{array}$ & $\begin{array}{c}0.653 \\
(0.818)\end{array}$ & $\begin{array}{c}0.203 \\
(1.065)\end{array}$ & $\begin{array}{c}0.065 \\
(0.965)\end{array}$ & $\begin{array}{c}0.038 \\
(0.956)\end{array}$ & $\begin{array}{c}-0.311 \\
(0.809)\end{array}$ \\
\hline Grad school & $\begin{array}{c}0.924 \\
(0.864)\end{array}$ & $\begin{array}{c}0.864 \\
(0.790)\end{array}$ & $\begin{array}{c}0.286 \\
(1.109)\end{array}$ & $\begin{array}{c}0.193 \\
(1.015)\end{array}$ & $\begin{array}{c}0.097 \\
(1.005)\end{array}$ & $\begin{array}{l}-0.451 \\
(0.755)\end{array}$ \\
\hline Subsidized lunch & $\begin{array}{c}-0.454 \\
(0.864)\end{array}$ & $\begin{array}{l}-0.455 \\
(0.931)\end{array}$ & $\begin{array}{c}-0.131 \\
(0.940)\end{array}$ & $\begin{array}{c}-0.106 \\
(0.975)\end{array}$ & $\begin{array}{c}0.006 \\
(1.070)\end{array}$ & $\begin{array}{c}0.231 \\
(1.089)\end{array}$ \\
\hline No sub. lunch & $\begin{array}{c}0.315 \\
(0.946)\end{array}$ & $\begin{array}{c}0.308 \\
(0.903)\end{array}$ & $\begin{array}{c}0.070 \\
(1.015)\end{array}$ & $\begin{array}{c}0.005 \\
(0.963)\end{array}$ & $\begin{array}{l}-0.031 \\
(0.932)\end{array}$ & $\begin{array}{l}-0.127 \\
(0.907)\end{array}$ \\
\hline
\end{tabular}


Table 2 - continued from previous page

\begin{tabular}{|c|c|c|c|c|c|c|}
\hline & $\begin{array}{l}\text { Math } \\
\text { score }\end{array}$ & $\begin{array}{c}\text { Reading } \\
\text { score }\end{array}$ & Homework & $\begin{array}{c}\text { Free } \\
\text { reading }\end{array}$ & $\begin{array}{c}\text { Computer } \\
\text { use }\end{array}$ & $\begin{array}{c}\text { TV } \\
\text { watching }\end{array}$ \\
\hline \multicolumn{7}{|l|}{ Mother's race } \\
\hline Black & $\begin{array}{l}-0.523 \\
(0.860)\end{array}$ & $\begin{array}{l}-0.501 \\
(0.908)\end{array}$ & $\begin{array}{l}-0.135 \\
(0.935)\end{array}$ & $\begin{array}{l}-0.128 \\
(0.951)\end{array}$ & $\begin{array}{c}0.073 \\
(1.125)\end{array}$ & $\begin{array}{c}0.419 \\
(1.123)\end{array}$ \\
\hline Hispanic & $\begin{array}{l}-0.181 \\
(0.895)\end{array}$ & $\begin{array}{c}-0.333 \\
(0.919)\end{array}$ & $\begin{array}{l}-0.096 \\
(0.926)\end{array}$ & $\begin{array}{l}-0.049 \\
(0.926)\end{array}$ & $\begin{array}{c}0.008 \\
(1.001)\end{array}$ & $\begin{array}{l}-0.044 \\
(0.916)\end{array}$ \\
\hline White & $\begin{array}{c}0.239 \\
(0.950)\end{array}$ & $\begin{array}{c}0.238 \\
(0.933)\end{array}$ & $\begin{array}{c}0.046 \\
(1.010)\end{array}$ & $\begin{array}{l}-0.009 \\
(0.977)\end{array}$ & $\begin{array}{l}-0.069 \\
(0.904)\end{array}$ & $\begin{array}{l}-0.169 \\
(0.878)\end{array}$ \\
\hline \multicolumn{7}{|c|}{ Mother's nativity } \\
\hline Native & $\begin{array}{l}-0.017 \\
(0.987)\end{array}$ & $\begin{array}{l}-0.010 \\
(0.988)\end{array}$ & $\begin{array}{c}-0.014 \\
(0.989)\end{array}$ & $\begin{array}{c}-0.051 \\
(0.969)\end{array}$ & $\begin{array}{l}-0.030 \\
(0.974)\end{array}$ & $\begin{array}{c}0.027 \\
(1.005)\end{array}$ \\
\hline Immigrant & $\begin{array}{c}0.114 \\
(0.990)\end{array}$ & $\begin{array}{l}-0.042 \\
(0.984)\end{array}$ & $\begin{array}{c}0.025 \\
(1.001)\end{array}$ & $\begin{array}{c}0.051 \\
(0.976)\end{array}$ & $\begin{array}{c}0.075 \\
(1.043)\end{array}$ & $\begin{array}{l}-0.146 \\
(0.906)\end{array}$ \\
\hline Observations & $4,882,823$ & $4,862,999$ & $3,869,819$ & $3,663,761$ & $3,218,859$ & $2,445,804$ \\
\hline
\end{tabular}

Sources: North Carolina Education Research Data Center and North Carolina State Center for Health Statistics. Standard errors in parentheses. 
Table 3: Correlations between outcomes

\begin{tabular}{lcccccc}
\hline \hline & $\begin{array}{c}\text { Math } \\
\text { score }\end{array}$ & $\begin{array}{c}\text { Reading } \\
\text { score }\end{array}$ & Homework & $\begin{array}{c}\text { Free } \\
\text { reading }\end{array}$ & $\begin{array}{c}\text { Computer } \\
\text { use }\end{array}$ & $\begin{array}{c}\text { TV } \\
\text { watching }\end{array}$ \\
\hline Math score & 1.000 & & & & & \\
Reading score & 0.752 & 1.000 & & & & \\
Homework & 0.195 & 0.165 & 1.000 & & & \\
Free reading & 0.153 & 0.216 & 0.141 & 1.000 & & \\
Computer use & -0.033 & -0.043 & 0.070 & 0.057 & 1.000 & \\
TV watching & -0.162 & -0.156 & -0.025 & -0.045 & 0.010 & 1.000 \\
\hline \hline
\end{tabular}

Sources: North Carolina Education Research Data Center and North Carolina State Center for Health Statistics. Sample: students in birth data. All outcomes standardized by grade and year.

Table 4: Correlations between own outcome and sibling outcome

\begin{tabular}{lcccccc}
\hline \hline & $\begin{array}{c}\text { Math } \\
\text { score }\end{array}$ & $\begin{array}{c}\text { Reading } \\
\text { score }\end{array}$ & Homework & $\begin{array}{c}\text { Free } \\
\text { reading }\end{array}$ & $\begin{array}{c}\text { Computer } \\
\text { use }\end{array}$ & $\begin{array}{c}\text { TV } \\
\text { watching }\end{array}$ \\
\hline Math score & 0.488 & & & & & \\
Reading score & 0.440 & 0.465 & & & & \\
Homework & 0.113 & 0.103 & 0.069 & & & \\
Free reading & 0.082 & 0.097 & 0.037 & 0.107 & & \\
Computer use & -0.015 & -0.022 & 0.012 & 0.002 & 0.076 & \\
TV watching & -0.163 & -0.154 & -0.043 & -0.033 & 0.009 & 0.214 \\
\hline \hline
\end{tabular}

Sources: North Carolina Education Research Data Center and North Carolina State Center for Health Statistics. Sample: students in birth data. All outcomes standardized by grade and year. 
Table 5: Correlations between outcomes by demographics

\begin{tabular}{lcccccccc}
\hline \hline & \multicolumn{2}{c}{ Homework } & \multicolumn{2}{c}{ Free reading } & \multicolumn{2}{c}{ Computer use } & \multicolumn{2}{c}{ TV watching } \\
\cline { 2 - 9 } & Math & Read & Math & Read & Math & Read & Math & Read \\
\hline All & 0.195 & 0.165 & 0.153 & 0.216 & -0.033 & -0.043 & -0.162 & -0.155 \\
Mother's education & & & & & & & & \\
< high school & 0.129 & 0.099 & 0.151 & 0.204 & -0.087 & -0.095 & -0.047 & -0.048 \\
High school & 0.158 & 0.127 & 0.135 & 0.197 & -0.073 & -0.079 & -0.103 & -0.100 \\
Some college & 0.177 & 0.145 & 0.125 & 0.202 & -0.036 & -0.045 & -0.151 & -0.148 \\
College & 0.189 & 0.155 & 0.107 & 0.206 & 0.005 & -0.008 & -0.205 & -0.198 \\
Graduate school & 0.181 & 0.150 & 0.116 & 0.222 & 0.034 & 0.019 & -0.220 & -0.218 \\
& & & & & & & & \\
Father's education & & & & & & & & \\
Missing & 0.127 & 0.096 & 0.157 & 0.205 & -0.085 & -0.093 & -0.015 & -0.014 \\
$<$ high school & 0.136 & 0.106 & 0.140 & 0.199 & -0.073 & -0.082 & -0.046 & -0.046 \\
High school & 0.161 & 0.131 & 0.129 & 0.197 & -0.061 & -0.067 & -0.103 & -0.101 \\
Some college & 0.175 & 0.142 & 0.119 & 0.200 & -0.030 & -0.039 & -0.132 & -0.133 \\
College & 0.185 & 0.151 & 0.101 & 0.201 & 0.004 & -0.008 & -0.185 & -0.181 \\
Graduate school & 0.186 & 0.152 & 0.101 & 0.210 & 0.035 & 0.014 & -0.203 & -0.198 \\
Subsidized lunch & 0.126 & 0.096 & 0.161 & 0.208 & -0.099 & -0.101 & -0.038 & -0.036 \\
No sub. lunch & 0.198 & 0.165 & 0.143 & 0.212 & -0.019 & -0.025 & -0.163 & -0.157 \\
Mother's race & & & & & & & & \\
Black & & & & & & & & \\
Hispanic & 0.130 & 0.102 & 0.144 & 0.192 & -0.062 & -0.069 & 0.021 & 0.023 \\
White & 0.161 & 0.129 & 0.141 & 0.205 & -0.078 & -0.095 & -0.026 & -0.030 \\
\hline \hline & 0.194 & 0.162 & 0.137 & 0.215 & 0.012 & 0.001 & -0.123 & -0.123 \\
\hline \hline
\end{tabular}

Sources: North Carolina Education Research Data Center and North Carolina State Center for Health Statistics. Sample: students in birth data. All outcomes standardized by grade and year. 
Table 6: Outcome regression results

\begin{tabular}{|c|c|c|c|c|c|c|}
\hline & $\begin{array}{l}\text { Math } \\
\text { score }\end{array}$ & $\begin{array}{c}\text { Reading } \\
\text { score }\end{array}$ & Homework & $\begin{array}{c}\text { Free } \\
\text { reading }\end{array}$ & $\begin{array}{c}\text { Computer } \\
\text { use }\end{array}$ & $\begin{array}{c}\text { TV } \\
\text { watching }\end{array}$ \\
\hline Lagged outcome & $\begin{array}{c}0.788 \\
(0.000)\end{array}$ & $\begin{array}{c}0.756 \\
(0.000)\end{array}$ & $\begin{array}{c}0.195 \\
(0.000)\end{array}$ & $\begin{array}{c}0.397 \\
(0.000)\end{array}$ & $\begin{array}{c}0.178 \\
(0.000)\end{array}$ & $\begin{array}{c}0.418 \\
(0.000)\end{array}$ \\
\hline \multicolumn{7}{|l|}{ Mother's education } \\
\hline High school & $\begin{array}{c}0.046 \\
(0.001)\end{array}$ & $\begin{array}{c}0.051 \\
(0.001)\end{array}$ & $\begin{array}{c}0.017 \\
(0.001)\end{array}$ & $\begin{array}{c}0.018 \\
(0.001)\end{array}$ & $\begin{array}{l}-0.006 \\
(0.002)\end{array}$ & $\begin{array}{c}0.006 \\
(0.002)\end{array}$ \\
\hline Some college & $\begin{array}{c}0.080 \\
(0.001)\end{array}$ & $\begin{array}{c}0.089 \\
(0.001)\end{array}$ & $\begin{array}{c}0.046 \\
(0.002)\end{array}$ & $\begin{array}{c}0.042 \\
(0.002)\end{array}$ & $\begin{array}{l}-0.004 \\
(0.002)\end{array}$ & $\begin{array}{l}-0.011 \\
(0.002)\end{array}$ \\
\hline College & $\begin{array}{c}0.127 \\
(0.001)\end{array}$ & $\begin{array}{c}0.126 \\
(0.001)\end{array}$ & $\begin{array}{c}0.084 \\
(0.002)\end{array}$ & $\begin{array}{c}0.054 \\
(0.002)\end{array}$ & $\begin{array}{c}0.002 \\
(0.003)\end{array}$ & $\begin{array}{l}-0.067 \\
(0.003)\end{array}$ \\
\hline Graduate school & $\begin{array}{c}0.145 \\
(0.002)\end{array}$ & $\begin{array}{c}0.144 \\
(0.002)\end{array}$ & $\begin{array}{c}0.100 \\
(0.003)\end{array}$ & $\begin{array}{c}0.092 \\
(0.003)\end{array}$ & $\begin{array}{c}0.006 \\
(0.003)\end{array}$ & $\begin{array}{l}-0.098 \\
(0.004)\end{array}$ \\
\hline \multicolumn{7}{|l|}{ Father's education } \\
\hline Higl & $\begin{array}{c}0.044 \\
(0.001)\end{array}$ & $\begin{array}{c}0.049 \\
(0.001)\end{array}$ & $\begin{array}{c}0.028 \\
(0.002)\end{array}$ & $\begin{array}{c}0.018 \\
(0.002)\end{array}$ & $\begin{array}{c}0.004 \\
(0.002)\end{array}$ & $\begin{array}{l}-0.028 \\
(0.002)\end{array}$ \\
\hline Some college & $\begin{array}{c}0.073 \\
(0.001)\end{array}$ & $\begin{array}{c}0.080 \\
(0.001)\end{array}$ & $\begin{array}{c}0.054 \\
(0.002)\end{array}$ & $\begin{array}{c}0.049 \\
(0.002)\end{array}$ & $\begin{array}{c}0.007 \\
(0.002)\end{array}$ & $\begin{array}{l}-0.054 \\
(0.002)\end{array}$ \\
\hline College & $\begin{array}{c}0.109 \\
(0.001)\end{array}$ & $\begin{array}{c}0.108 \\
(0.001)\end{array}$ & $\begin{array}{c}0.083 \\
(0.002)\end{array}$ & $\begin{array}{c}0.048 \\
(0.002)\end{array}$ & $\begin{array}{c}0.017 \\
(0.003)\end{array}$ & $\begin{array}{c}-0.109 \\
(0.003)\end{array}$ \\
\hline Graduate school & $\begin{array}{c}0.137 \\
(0.002)\end{array}$ & $\begin{array}{c}0.137 \\
(0.002)\end{array}$ & $\begin{array}{c}0.113 \\
(0.003)\end{array}$ & $\begin{array}{c}0.100 \\
(0.003)\end{array}$ & $\begin{array}{c}0.031 \\
(0.003)\end{array}$ & $\begin{array}{l}-0.145 \\
(0.003)\end{array}$ \\
\hline Black & $\begin{array}{l}-0.152 \\
(0.001)\end{array}$ & $\begin{array}{l}-0.184 \\
(0.001)\end{array}$ & $\begin{array}{l}-0.126 \\
(0.001)\end{array}$ & $\begin{array}{l}-0.073 \\
(0.001)\end{array}$ & $\begin{array}{c}0.081 \\
(0.001)\end{array}$ & $\begin{array}{c}0.359 \\
(0.001)\end{array}$ \\
\hline Hispanic & $\begin{array}{l}-0.121 \\
(0.001)\end{array}$ & $\begin{array}{l}-0.189 \\
(0.001)\end{array}$ & $\begin{array}{l}-0.093 \\
(0.002)\end{array}$ & $\begin{array}{l}-0.101 \\
(0.002)\end{array}$ & $\begin{array}{c}0.066 \\
(0.002)\end{array}$ & $\begin{array}{c}0.078 \\
(0.002)\end{array}$ \\
\hline Other race & $\begin{array}{c}0.047 \\
(0.001)\end{array}$ & $\begin{array}{l}-0.056 \\
(0.001)\end{array}$ & $\begin{array}{c}0.027 \\
(0.002)\end{array}$ & $\begin{array}{c}0.034 \\
(0.002)\end{array}$ & $\begin{array}{c}0.123 \\
(0.003)\end{array}$ & $\begin{array}{c}0.027 \\
(0.003)\end{array}$ \\
\hline Multiracial & $\begin{array}{c}-0.049 \\
(0.001)\end{array}$ & $\begin{array}{l}-0.049 \\
(0.001)\end{array}$ & $\begin{array}{l}-0.043 \\
(0.003)\end{array}$ & $\begin{array}{c}0.005 \\
(0.002)\end{array}$ & $\begin{array}{c}0.014 \\
(0.003)\end{array}$ & $\begin{array}{c}0.144 \\
(0.003)\end{array}$ \\
\hline Female & $\begin{array}{c}0.023 \\
(0.000)\end{array}$ & $\begin{array}{c}0.052 \\
(0.000)\end{array}$ & $\begin{array}{c}0.063 \\
(0.001)\end{array}$ & $\begin{array}{c}0.188 \\
(0.001)\end{array}$ & $\begin{array}{c}0.069 \\
(0.001)\end{array}$ & $\begin{array}{l}-0.075 \\
(0.001)\end{array}$ \\
\hline Birth data & $\begin{array}{l}-0.130 \\
(0.052)\end{array}$ & $\begin{array}{l}-0.097 \\
(0.057)\end{array}$ & $\begin{array}{c}0.060 \\
(0.100)\end{array}$ & $\begin{array}{c}0.231 \\
(0.099)\end{array}$ & $\begin{array}{c}0.036 \\
(0.116)\end{array}$ & $\begin{array}{l}-0.067 \\
(0.108)\end{array}$ \\
\hline Mother age & $\begin{array}{c}0.001 \\
(0.000)\end{array}$ & $\begin{array}{c}0.002 \\
(0.000)\end{array}$ & $\begin{array}{c}0.002 \\
(0.000)\end{array}$ & $\begin{array}{l}-0.000 \\
(0.000)\end{array}$ & $\begin{array}{c}0.002 \\
(0.000)\end{array}$ & $\begin{array}{c}0.001 \\
(0.000)\end{array}$ \\
\hline
\end{tabular}

Continued on next page 
Table 6 - continued from previous page

\begin{tabular}{lcccccc}
\hline \hline & Math & Reading & \multicolumn{2}{c}{ Free } & Computer & TV \\
& score & score & Homework & reading & use & watching \\
\hline Mother married & -0.005 & -0.003 & 0.003 & 0.000 & 0.003 & -0.009 \\
& $(0.001)$ & $(0.001)$ & $(0.002)$ & $(0.001)$ & $(0.002)$ & $(0.002)$ \\
Mother immigrant & 0.060 & 0.057 & 0.014 & 0.054 & 0.015 & -0.023 \\
& $(0.001)$ & $(0.002)$ & $(0.003)$ & $(0.003)$ & $(0.003)$ & $(0.004)$ \\
No father & 0.015 & 0.020 & 0.020 & -0.002 & 0.017 & -0.010 \\
information & $(0.002)$ & $(0.002)$ & $(0.004)$ & $(0.004)$ & $(0.005)$ & $(0.004)$ \\
Father age & -0.000 & -0.000 & 0.000 & 0.000 & 0.001 & 0.001 \\
& $(0.000)$ & $(0.000)$ & $(0.000)$ & $(0.000)$ & $(0.000)$ & $(0.000)$ \\
Father immigrant & 0.042 & 0.049 & 0.010 & 0.047 & 0.014 & -0.006 \\
& $(0.001)$ & $(0.002)$ & $(0.003)$ & $(0.003)$ & $(0.003)$ & $(0.004)$ \\
First born & 0.021 & 0.042 & 0.034 & 0.043 & 0.023 & -0.006 \\
& $(0.001)$ & $(0.001)$ & $(0.001)$ & $(0.001)$ & $(0.001)$ & $(0.001)$ \\
Birth weight & 0.006 & 0.004 & 0.001 & -0.001 & 0.001 & 0.005 \\
& $(0.000)$ & $(0.000)$ & $(0.000)$ & $(0.000)$ & $(0.000)$ & $(0.000)$ \\
Alcohol when & 0.008 & 0.003 & -0.001 & -0.008 & -0.008 & -0.033 \\
pregnant & $(0.002)$ & $(0.002)$ & $(0.004)$ & $(0.004)$ & $(0.005)$ & $(0.004)$ \\
Tobacco when & -0.033 & -0.026 & -0.018 & 0.018 & -0.001 & 0.020 \\
pregnant & $(0.001)$ & $(0.001)$ & $(0.001)$ & $(0.001)$ & $(0.002)$ & $(0.002)$ \\
\hline Observations & $8,287,683$ & $8,247,200$ & $6,682,110$ & $5,848,259$ & $5,127,654$ & $4,464,194$ \\
$R^{2}$ & 0.706 & 0.651 & 0.118 & 0.190 & 0.098 & 0.260 \\
$F$-stat for FE & 11.64 & 4.97 & 7.38 & 2.78 & 6.01 & 2.72 \\
\hline
\end{tabular}

Sources: North Carolina Education Research Data Center and North Carolina State Center for Health Statistics. Standard errors in parentheses. 
Table 7: The effect of a family shock by demographics

\begin{tabular}{|c|c|c|c|c|c|c|}
\hline & $\begin{array}{l}\text { Math } \\
\text { score }\end{array}$ & $\begin{array}{c}\text { Reading } \\
\text { score }\end{array}$ & Homework & $\begin{array}{c}\text { Free } \\
\text { reading }\end{array}$ & $\begin{array}{c}\text { Computer } \\
\text { use }\end{array}$ & $\begin{array}{c}\text { TV } \\
\text { watching }\end{array}$ \\
\hline All & 0.133 & 0.149 & 0.144 & 0.200 & 0.178 & 0.247 \\
\hline \multicolumn{7}{|l|}{ Mother's education } \\
\hline Less than high school & 0.127 & 0.155 & 0.087 & 0.162 & 0.177 & 0.248 \\
\hline High school & 0.131 & 0.149 & 0.141 & 0.178 & 0.174 & 0.253 \\
\hline Some college & 0.131 & 0.145 & 0.151 & 0.222 & 0.175 & 0.245 \\
\hline College & 0.147 & 0.144 & 0.196 & 0.251 & 0.187 & 0.230 \\
\hline Graduate school & 0.150 & 0.148 & 0.205 & 0.272 & 0.197 & 0.239 \\
\hline \multicolumn{7}{|l|}{ Father's education ${ }^{\mathrm{a}}$} \\
\hline Less than high school & 0.132 & 0.159 & 0.129 & 0.177 & 0.177 & 0.245 \\
\hline High school & 0.130 & 0.145 & 0.137 & 0.189 & 0.167 & 0.242 \\
\hline Some college & 0.137 & 0.150 & 0.161 & 0.229 & 0.157 & 0.244 \\
\hline College & 0.152 & 0.149 & 0.185 & 0.250 & 0.188 & 0.240 \\
\hline Graduate school & 0.152 & 0.143 & 0.210 & 0.260 & 0.203 & 0.239 \\
\hline Subsidized lunch & 0.128 & 0.157 & 0.119 & 0.168 & 0.190 & 0.261 \\
\hline No subsidized lunch & 0.140 & 0.149 & 0.165 & 0.203 & 0.157 & 0.231 \\
\hline Mother unmarried & 0.129 & 0.151 & 0.110 & 0.164 & 0.213 & 0.263 \\
\hline Mother married ${ }^{\mathrm{b}}$ & 0.135 & 0.149 & 0.155 & 0.212 & 0.168 & 0.241 \\
\hline \multicolumn{7}{|l|}{ Mother's race/ethnicity } \\
\hline Black & 0.121 & 0.148 & 0.122 & 0.166 & 0.211 & 0.278 \\
\hline Hispanic & 0.151 & 0.165 & 0.193 & 0.183 & 0.217 & 0.240 \\
\hline White & 0.137 & 0.148 & 0.152 & 0.215 & 0.162 & 0.226 \\
\hline Immigrant mother & 0.155 & 0.165 & 0.200 & 0.241 & 0.208 & 0.275 \\
\hline Native mother & 0.132 & 0.148 & 0.142 & 0.198 & 0.177 & 0.247 \\
\hline Sibling-pair observations & 825,830 & 818,228 & 590,258 & 602,517 & 485,927 & 368,832 \\
\hline
\end{tabular}

Sources: North Carolina Education Research Data Center and North Carolina State Center for Health Statistics. All outcomes in standard-deviation units.

${ }^{a}$ For sibling pairs with the same father's education.

$\mathrm{b}$ For siblings with the same marital status for the mother at the time of birth. 
Table 8: Correlations between family shocks

\begin{tabular}{lcccccc}
\hline \hline & $\begin{array}{c}\text { Math } \\
\text { score }\end{array}$ & $\begin{array}{c}\text { Reading } \\
\text { score }\end{array}$ & Homework & $\begin{array}{c}\text { Free } \\
\text { reading }\end{array}$ & $\begin{array}{c}\text { Computer } \\
\text { use }\end{array}$ & $\begin{array}{c}\text { TV } \\
\text { watching }\end{array}$ \\
\hline Math score & 1.000 & & & & & \\
Reading score & 0.820 & 1.000 & & & & \\
Homework & 0.327 & 0.279 & 1.000 & & & \\
Free reading & 0.224 & 0.343 & 0.276 & 1.000 & & \\
Computer use & -0.095 & -0.100 & 0.091 & 0.014 & 1.000 & \\
TV watching & -0.118 & -0.055 & -0.101 & -0.024 & -0.060 & 1.000 \\
\hline \hline
\end{tabular}

Sources: North Carolina Education Research Data Center and North Carolina State Center for Health Statistics. Sample: students in birth data. 


\section{Appendix}

Table A.1: Conversion of time use categories to continuous values

\begin{tabular}{|c|c|c|}
\hline Response $^{\mathrm{a}}$ & $\begin{array}{l}\text { Relative } \\
\text { frequency }\end{array}$ & $\begin{array}{l}\text { Assigned } \\
\text { value }\end{array}$ \\
\hline Time on homework & & $h r s / w k$ \\
\hline Has homework, but does not do it & 0.013 & 0 \\
\hline Less than one hour each week & 0.302 & 0.5 \\
\hline Between 1 and 3 hours & 0.409 & 2 \\
\hline More than 3 but less than 5 hours & 0.148 & 4 \\
\hline Between 5 and 10 hours & 0.094 & 7.5 \\
\hline More than 10 hours & 0.019 & 12 \\
\hline No homework is ever assigned & 0.015 & dropped \\
\hline Amount of time spent free reading & & $h r s / d a y$ \\
\hline None & 0.116 & 0 \\
\hline About 30 minutes & 0.481 & 0.5 \\
\hline About 1 hour & 0.213 & 1 \\
\hline Between 1 and 2 hours & 0.121 & 1.5 \\
\hline More than 2 hours & 0.070 & 2.5 \\
\hline Student uses computer at home & & days/mo \\
\hline I use a computer at home for school work almost every day & 0.067 & 24 \\
\hline Once or twice a week & 0.167 & 6 \\
\hline Once or twice a month & 0.182 & 1.5 \\
\hline Hardly ever & 0.307 & 0.5 \\
\hline Never, even though there is a computer at home & 0.154 & 0 \\
\hline There is no computer at home & 0.123 & dropped \\
\hline TV watched at home each school day & & hrs/day \\
\hline None & 0.045 & 0 \\
\hline 1 hour or less each school day & 0.258 & 0.5 \\
\hline 2 hours & 0.256 & 2 \\
\hline 3 hours & 0.201 & 3 \\
\hline 4 to 5 hours & 0.144 & 4.5 \\
\hline 6 hours or more & 0.097 & 7 \\
\hline
\end{tabular}

Source: North Carolina Education Research Data Center.

${ }^{a}$ Variable titles and labels as they appear in the codebook. 